\title{
Academic Quality Assurance Survey in Higher Education
}

\author{
M. Zaki ${ }^{1}$ \\ ${ }^{1}$ Tadris IPS, Faculty of Education and Teachers Training, Universitas Islam Negeri Mataram, Jalan Gajahmada 100 \\ Jempong Baru, Mataram, West Nusa Tenggara, Indonesia \\ Correspondence: M. Zaki, Tadris IPS, Faculty of Education and Teachers Training, Universitas Islam Negeri \\ Mataram, Jalan Gajahmada 100 Jempong Baru, Mataram, West Nusa Tenggara, Indonesia.
}

Received: August 26, 2020

Accepted: September 30, 2020

Online Published: October 3, 2020

doi:10.5430/ijhe.v9n6p268

URL: https://doi.org/10.5430/ijhe.v9n6p268

\begin{abstract}
State Islamic University of Mataram (UIN Mataram) is the only Higher Education institution which is located in central of Indonesia and leads to its vision as World Class University (WCU) in 2042 by managing 32 study programs including sciences and socials. Furthermore, it has huge responsibility to develop the quality of education in local and national scopes which then required good academic quality control. The present study aims to describe and analyze the responses on the academic service at Faculty of Education and Teachers Training at UIN Mataram in 2018 and 2019. The research approach was quantitative model with the survey design. The instruments used was online and offline questionnaires with the collaboration with Quality Assurance Bureau (QAB) at the university. According to the findings of the study, the conclusion was: (1) the students' satisfaction on the lecturers' performance increased 0.014 in 2019, (2) TBI (English Education Department) showed significant improvement of lecturers' performance score (0.24) in 2019, and (3) the lecturers' punctuality to teach had been the item to show the highest score margin between 2018 and $2019(0.24)$. The present research imply the urgency to adjust the weakness of the academic quality to the better condition.
\end{abstract}

Keywords: higher education, quality assurance, lecturers' performance, academic

\section{Introduction}

Improving the quality of education is a strategic choice when it is associated with the increasing demands of competition in all fields on national and global scope. As part of the education units at the education level and path, higher education has a strategic role. Higher education institutions have turned into international institutions and quality management is very consumer-oriented both in local and global markets. Therefore, universities have to put in serious attention some matters related to its performance assessment, marketing, and international competition by paying attention on assuring its education quality.

There have been some ideas defining quality assurance (QA). Vlăsceanu, Grünberg, \& Pârlea (2007) state that quality assurance deals with the in progress and sustainable process of evaluation toward preserving the quality of education in various levels, programs, systems, or institutions. Lately, university as the higher education has put tremendous attention to keep their education quality as manifestation toward global competition. The present attention has been the reflection and response toward the hope of acquiring the better quality of education. Hence, every university in the world competitively and actively struggles to gain its institutional goals to maintain public trust and satisfaction, as well as the needs of the stakeholders (Saed \& Saed, 2018). Furthermore, Suhendro (2003) mentions that the existence of higher education in society is influenced by its attempt to keep the institution goal in line with consumers expectation. Later on, the higher education policy and management strategy for the quality assurance are affected by the society, prominently the prospective students and the current students.

The quality of a higher education can be measured from three aspects, namely competence, accreditation, and accountability which the role of students as the ongoing academician or graduates is influential. Graduates as the output of the education in higher education must meet the qualifications of the institutions with good competence, accreditation, and accountability which are reflected from their certificate (Rusdarti, 2017). A professional graduate is also affected by the existence of professional lecturers as the tutor and guide to meet the required academic goal. Pakpahan (2017) mentions that to get the professional human resources the institution must pay attention on recruitment and selection process, capacity training, and developing the prospective workers which may be in the form of academic quality assurance (AQA). 
Efforts to enhance the quality of academic performance have been implemented, but the results have not been encouraging. The emergence of an effort to implement the University-Based Curriculum Management is influenced by several factors. Pakapan (2017) explains that there are various factors that cause the quality of education is still far from the expected. The evaluation result of the Directorate General of Higher Education Ministry of National Education (2000) shows that the average time a student completes his studies is still too long compared to the time given by the study program. For example for 1999/2000, only 51\% of undergraduate students could complete their studies as expected. In addition, the productivity of graduates, namely the ratio between graduates and the number of students is still unsatisfactory, especially in the S1 program at state Islamic universities (PTKIN), a declining trend. Although there are many influential factors, this fact is one indication of the achievement of low quality in the higher education system (Suhendro, 2003).

State Islamic University of Mataram (UIN Mataram) as the only Islamic university in West Nusa Tenggara Indonesia hands huge responsibility to produce the graduates that are academically professional and religious. The university has made a lot of improvements in different aspects such as constructing thirteen international standards buildings for supporting academic process, increasing more cooperation with many different institutions and agents for escalating research and public services, and implementing periodical academic quality assurance (AQA) toward its academic performance. As the reflection of fact that many students were hardly finish their study in university, UIN Mataram has implement quality assurance system which is assisted by the Quality Assurance Bureau (QAB) yearly.

AQA has been importance issue every year that makes many researchers have been interested to seek for pedagogical insight about it. First, Setiyaningrum (2012). She states that the implementation of TQM is very beneficial for the life of the organization, as well as developing a more supportive organizational culture to increase employee performance so that the achievement of organizational goals can be realized optimally. Second, Anggraeni (2014) states that AQA is very important to maintain and develop lecturers' performance. While, lecturers' performance would influence the development of institution in terms of having effective education implementation. Bancin (2017) states that AQA is an absolute need for university to gain better academic recognition. The three researches have shown that AQA plays important role to the development of education quality. Unfortunately, there was no similar context which was discussed to draw generalization. Then, the lecturers' performances in higher education in different departments have not yet been discussed.

According to the previous description, the present research was intended to discuss the implementation of AQA to monitor the Faculty of Education and Teachers Training, UIN Mataram lecturers' performances by looking at different department where they teach and items of performances in the questionnaires point of view. Hence, the present research was entitled academic quality assurance survey in higher education.

\section{Literature Review}

\subsection{Previous Studies}

There are some researches which discussing the implementation of Quality Assurance in various level of education. First, a study entitled Impact of Quality Assurance on Academic Performance by Sameerah (2018). She conducted research in Ishik University, Erbil, Iraq. Thus, her study aimed to identify the importance of quality assurance to escalate the academic performance in the university where the study was done. The focus of the study was to check the productivity, quality, and ranking in the area of teaching and learning. Her study highlighted the problematic challenges, the variety level of achievements, and giving overcoming suggestions for improvements. She used a qualitative content analysis study which the data were taken from the administration of questionnaire and interview. The findings showed that the implementation of rigid quality assurance produced a very fundamental changes and inclining standard during the teaching and learning process, improvement of research products, and upgrading the university ranking in worldwide education ranking.

Second, a study entitled "Academic Quality Assurance System Madrasah Targets Madrasah Aliyah Development Project in Central Java" that was conducted by Suratno and Ida Zulaeha (2019). Their study was directed to discuss the strength and weaknesses of the AQAS (academic quality assurance system) in Islamic high schools that was chosen by MEDP in central Java. The approach of the research was CIPP evaluative model by focusing on three different Islamic high school namely: MA NU Limpung (integrated madrasah), MA YSPIS (madrasah pesantren), and MA Al Irsyad (independent madrasah). The researchers used three instruments during the research to gather the data, they are: interview, close-ended questionnaires, and documentation. Later, the researcher implemented analytical descriptive method to analyze the collected data. The results showed that the quality assurance needed to be socialized to the society before its implementation, to be specific in the Central Java where the awareness of AQAS were not high. Also, there was need to set a standard of AQAS specially for Islamic high school which has different condition with public high school. 
Third, a research that was conducted by Reddy Siram (2015) "Manajemen Penjaminan Mutu Layanan Akademik Perguruan Tinggi". This was a case study research that investigate the management of quality assurance by considering some points: 1) the academic service, 2) the input of quality assurance, 3) the process of teaching and learning, 4) the preparation of infrastructures and facilities, and 5) the output (graduates). There were five departments which were included as the population as sample. The departments were the Physical Education, Education Administration, Non-formal Education, and Health and Recreation. The conclusion of his research said that many students who graduated from the university did not get job that similar with their study program when studying in university. Consequently, the need of precise quality assurance to meet and tackle this fact was very important.

Fourth, a study with the title "Sistem Penjaminan Mutu Perguruan Tinggi" by Bancin (2017). The present study was intended to discuss or assess the quality assurance system of universities. A chosen method for the research was library research that is objective, systematic, analytical, and descriptive. The result of the study emphasized the important of the sustainable presence of quality assurance in higher education. The quality assurance must be implemented in line with vision and mission of the institution, meeting the internal needs, compiling the goals of the stakeholders of the institution to do university Tridharma. In short, the implementation of quality assurance in university was absolute together with the good control of quality management.

\subsection{The Academic Quality Assurance}

The demand to be the leading institution in the international competition has triggered higher education to manage better their academic performance to be more accountable and transparence. Moreover, it also challenges the university to develop the quality culture matching with its diversities in every area together match with the ability to surpass the obstacles in higher education globally (Smidt, 2015). Consequently, all higher education needs to grab every chance in order to get the external and internal trusts and one of them is by keeping the quality assurance (QA). The simple definition of QA is basically about giving the third party, independent, external, and objective overviews. The serious reviews are implemented on some aspects such as the university programs, the collaborative works with other institutions, the academic services, and the process of education and administration implementation which all of them will be accompanied by the recommendation for better quality. In addition, many different perspectives, dimensions, and contexts appear when the QA is applied to maintain the quality of students and lecturers (Smidt, 2015). Several main dimensions to assure the quality of tertiary education are vale, meeting needs and expectations, excellence service, and consistency; while still no QA system that is able to evaluate a university with all those aspects unless the university select the quality item needed to be assure earlier (Harvey, 2014).

The implementation of QA in general will serve the consistent assessment in learning pedagogy, design, and content (Puzziferro \& Shelton, 2008). However, there have been some ideas to define the quality of education in university. Barnet (1992) mentions that the quality of tertiary education is reflected by two conceptions. The first conception is about how the institution will provide contribution toward the issue that arisen in the society. The second conception lays on how the higher education performs qualified actions which is seen from its inputs and outputs. Hence, the quality of institutions is captured from their performance that is measured using performance indicators. Lundberg \& Schreiner (2004) state that the interaction among faculties and students also become another conception of tertiary education qualification.

Some scholars have defined the quality assurance in university or higher education in some literary products. Schindler et. al. (2015) tried to formulate the definition of quality assurance by mentioning two main strategies. It means that how the implementation of QA in higher education is importantly paying attention to the strategies of the process. Some other authors formulate the definitions of QA in higher education by looking at the central target and goal or even the outcome of its implementation. On the different sides, the definition of QA in higher education is identified by the reflection of qualified inputs (students, academic staffs, others) and the desired outputs (acceptance in the workplace).

Considering some different ideas on defining the concept of quality assurance in higher education, Schindler et al. (2015) characterize the main concept of quality in tertiary education are about transformative, accountable, purposeful, and exceptional. The possible factors that may influence the current challenge to define Quality in higher education is because the region diversities of the institution that may influence the perspective to see it. Green, Marmolejo, \& Egron-Polak (2012) stated that some region do not put the quality assurance and accreditation as purely national undertaking and different region has different ways of jurisdiction to assure the education quality and accreditation program. 


\section{Method}

The aim of the present study was about to dig out the implementation of academic process in Faculty of Education and Teachers Training (FTK) at State Islamic University of Mataram (UIN Mataram) from the point of view students towards lecturers' performance in 2018 and 2019. Hence, the present study applied descriptive quantitative approach with survey design. The close ended online and offline questionnaire were administered to the university students in June 2018 and June 2019. The sample were the 500 students in 2018 and 510 students in 2019 who were from ten different departments in the Faculty of Education and Teachers Training (FTK).

The questionnaire was set in anonymous format by including thirteen statements about the lecturers' performance during the course preparation and classroom action. The statements for assessing lecturers' preparation refer to the lecturers' readiness to teach involving providing lesson plan and clear classroom assessment and lecturer punctuality to the class schedule. In addition, the further statements were about the classroom action which include some indicators such as: lecturers' method and strategy in teaching, lecturers' openness to accept any feedback and response from students, lecturers' clarity during course explanation, classroom attendance, lecturers' ability to equip media during teaching, students' intention and motivation to join class regarding the lecturers' performance, lecturers' integrity to teach, the required course objectives, and lecture time management.

The collected data were analyzed statistically using SPSS and transformed into graphic to provide general overview of lecturers' performance in two different years. Hinton, McMurray, \& Brownlow (2014) state that SPSS has been proved as the most effective software to be used in quantitative study to do statistical analysis and manage some data which enable researcher to generate ideas to grab the outcome of the research. The description of the graphics followed the pictures and discussed with the relevant theories.

\section{Findings and Discussion}

Regarding the objectives of the present research on finding the students' responses toward the lecturers' performance in higher education, the findings of the research was categorized into the identification of issue in two different years. In each year, the survey showed the data from two different points of views namely the lectures' performance in every different department and the lecturers' performance seen from every single questionnaire items.

\subsection{The Lecturers' Performance in 2019}

The following are the data which have been transformed into graphic to create accumulative and clear information of the Faculty of Education and Teachers Training (FTK) at State Islamic University of Mataram (UIN Mataram) lecturers in 2019 from the perspectives of students.

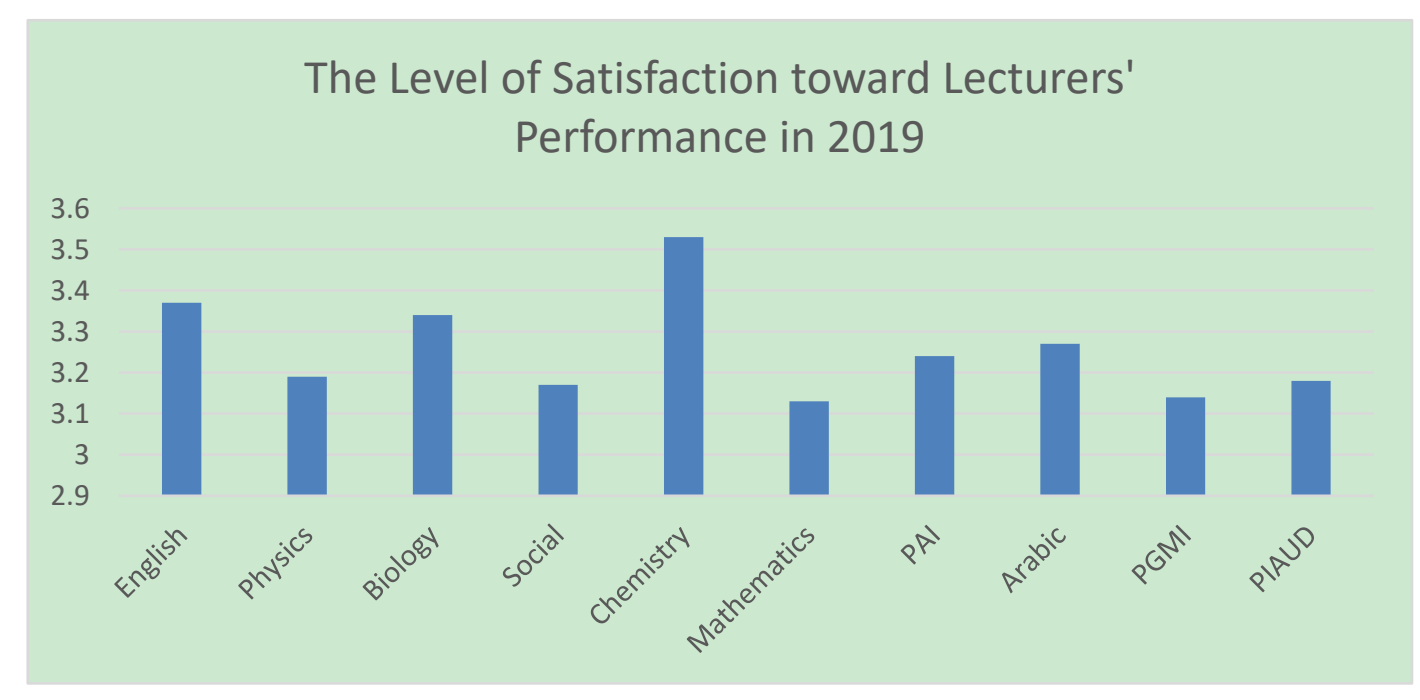

Figure 1. Lecturers' Performance in 2019 from Different Departments

Figure 1 shows the students' satisfaction on lecturers' performance were various in every different Departments in Faculty of Education and Teachers Training. The highest students' satisfaction level was gathered in Chemistry department with 3.53 points. The lowest satisfaction score was perceived by Mathematics Department with 3.13 points. The average students' satisfaction score on the lecturers' performance in all departments in 2019 was 3.256. 


\section{The Average Percentage of Survey Items on the Satisfaction toward Lecturers' Performance in 2019}

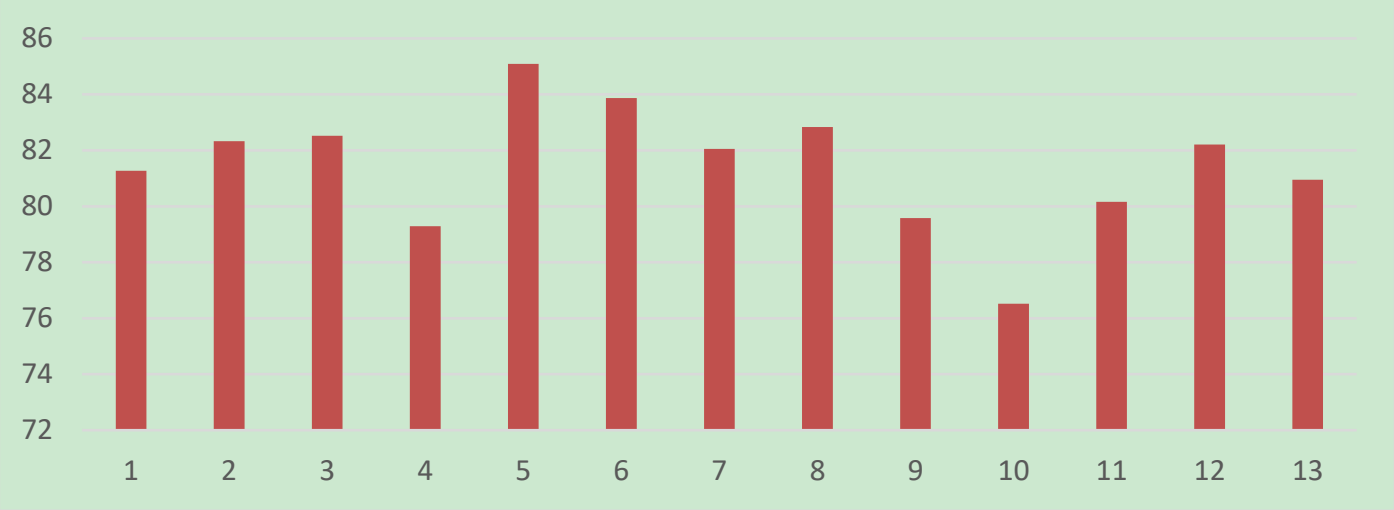

Figure 2. Lecturers' Performance in 2019 from Different Items in Questionnaires

Figure 2 describes the students' satisfaction on lecturers' performance by discussing the score of each items in the questionnaire. There were thirteen statement in the questionnaires that were asked to get students' responses by choosing strongly disagree to strongly agree. The figure explains that students were very satisfied by the availability of freedom to share ideas and opinion related to the given topic as well as the lecturers' actively provide opportunity to ask something that students have not yet mastered. This questionnaire item hit average score of 85.09 . On the opposite side, the lecturers' creativity to provide variety of teaching method and to use various media in teaching were still less satisfactory with only 76.52 score. Though, the mentioned score was still above the minimum standard of being good category. The average students' satisfaction score on the lecturers' performance from the questionnaire items score accumulation in 2019 was 81.44 .

\subsection{The Lecturers' Performance in 2018}

The following are the data which have been transformed into graphic to create accumulative and clear information of the Faculty of Education and Teachers Training (FTK) at State Islamic University of Mataram (UIN Mataram) lecturers in 2018 from the perspectives of students.

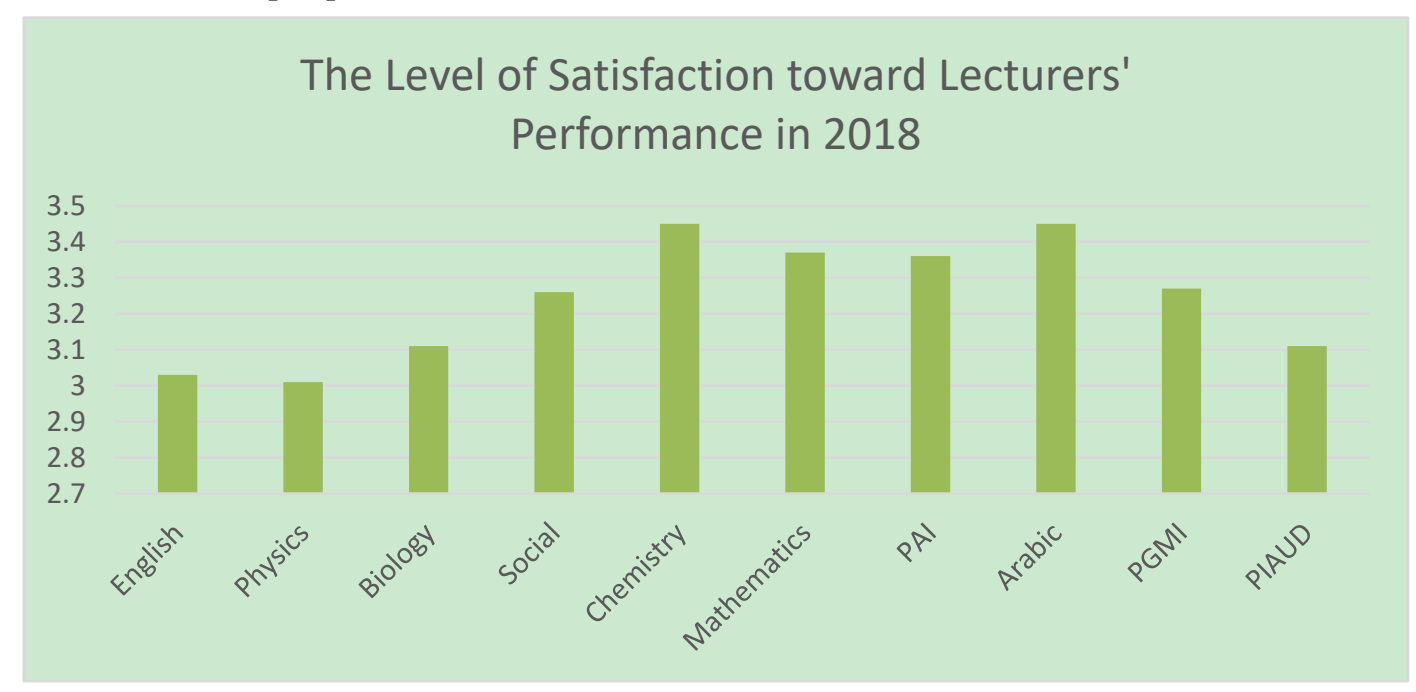

Figure 3. Lecturers' Performance in 2018 from Different Departments

Figure 3 shows the students' satisfaction on lecturers' performance were various in every different Departments in Faculty of Education and Teachers Training. The highest students' satisfaction level was gathered in Chemistry department and Arabic department with similar score 3.45 points. The lowest satisfaction score was perceived by Physics Department with 3.01 points. The average students' satisfaction score on the lecturers' performance in all departments in 2019 was 3.242 . 


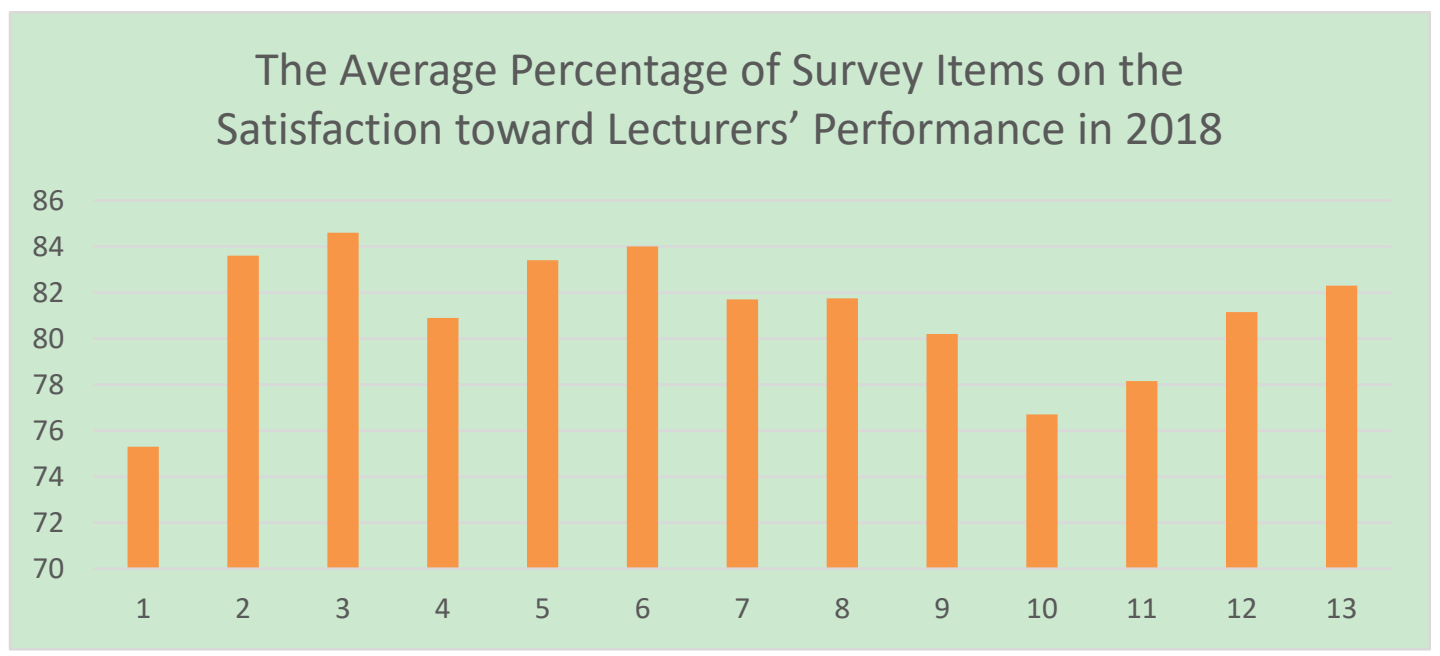

Figure 4. Lecturers' Performance in 2018 from Different Items in Questionnaires

Figure 4 describes the students' satisfaction on lecturers' performance by discussing the score of each items in the questionnaire. There were thirteen statement in the questionnaires that were asked to get students' responses by choosing strongly disagree to strongly agree. The figure explains that students were very satisfied by lecturers' openness on the course assessment system which were explained in detail in the course outline and it was explained more in the first meeting of the course. This questionnaire item hit average score of 84.06. unfortunately, the lecturers' discipline to come on time to the class were still less satisfactory with only 75.30 score. Though, the mentioned score was still above the minimum standard of being good category. The average students' satisfaction score on the lecturers' performance from the questionnaire items score accumulation in 2019 was 81.09.

\section{Discussion}

The findings of the present research revealed the different students' responses on the quality of the lecturers' performance in the process of teaching and learning in all departments in the faculty of Education and Teachers Training at UIN Mataram. The students' responses depicted some facts on: 1) score margins of lectures' performance between two years, 2) the best department with the highest score margin between the year of 2018 and 2019, and 3) the most satisfactory points from the lecturers' performance in two years.

The facts which had been described trough the figures above had shown that there was increasing score about 0.014 from the lecturers' performance in 2018 (3.242) to lecturer's performance in 2019 (3.256). There were some possibilities that cause the quality of the academic service in the form of lecturers' performance increased which one of them because of the AQA. The periodical report of the academic quality assurance has already been delivered to each lecturers' in the department. This system might trigger the lecturers to motivate themselves to improve their teaching performance for best service to the students. Saeed \& Saeed (2018) mentions that the implementation of the academic quality assurance has created significant changes and improvements on the lecturers' performance in teaching and research in the university as well as upgrading the rank of the university. Later on, when the lecturers' performance has increased in quality, there will impact the students' performance and outcome. Neihart (2017) states that the lecturers' readiness to teach will provide direct impact toward the students' outcomes.

The changes on the academic performance between both years has not only pictured from the lecturers' individual performance, but also from their departments as an entity. Figure 1 and figure 3 have shown that there were five departments (Social Education Department, Mathematics Department, Islamic Religion Education Department, Arabic Department, and Islamic Elementary School Teachers Department) which experienced declining academic performance in 2019. On the other hand, the other five departments (English Education Department, Physics Department, Biology Department, Chemistry Department, and Early Childhood Islamic Education Department. Comparing both conditions, the findings shows that the lecturers' performance that was seen from different departments in the faculty showed not satisfactory situation while the university hoped that more departments got more positive responses from students. Suarman et al. (2013) state that students admire good quality of teaching and learning process that enable them to have good interactions as well as good quality of higher education.

Departments in the university always seek for better academic performance every year as the evidence of positive changes for students' satisfaction. English Education Department (TBI) at UIN Mataram had depicted this attempt 
by having the highest academic performance score margin between 2018 and 2019 that was 0.24 . One of the possible reasons was because in 2019 the department registered itself to get its first national accreditation by the national board of accreditation for higher education. It means that the external quality assurance influences the internal department performance including individual lecturers' teaching performance. Liu (2015) research shows the indication of the external quality assurance influence toward the inner life of the university.

Dealing with the findings of the survey from the questionnaire items, the lecturers' habit for being ready to teach became the most changing items with 5.97 margin score between 2018 and 2019. The lecturers showed better punctuality in teaching in the recent year. Martin (2019) states that $80 \%$ students characterize a good lecturer by when the lecturer also keep to be punctual with the class schedule. On the opposite side, in 2019 the lecturers were scored lower (82.52) in term of providing clear course assessment compared with in 2018 (84.6). Looking at the geographical situation, it might be caused by the earthquake that hit Lombok island in the end of 2018 which influenced the process of teaching and learning in early 2019. The learning process was mediated by online using learning management system and offline in emergency tents that many deficiencies still affect their success. However, the overall scores on students' satisfaction toward lecturers' performance in 2019 was higher about 0.35 into 81.44

The increasing quality of the academic in the Faculty of Education and Teachers Training from the lecturers' performance point of view in 2019 explained that UIN Mataram had made adjustment on the weakness as suggested in the recommendation by the Quality Assurance Bureau at UIN Mataram. The lecturers' as the agent of academic promotion in the class also learned from the result of the previous year AQA results. Meanwhile, there were some points that need to take concern by the university and faculty to assure their quality of education such as the declining survey score for lecture method that did not trigger students to be active and the low frequency of media use to aid the teaching and learning process.

\section{Conclusions}

Academic quality assurance (AQA) is an absolute thing to apply in the university as higher education institution and the center of education. The survey study which was implemented to give the insight of lecturers' performance in the teaching and learning process in Faculty of Education and Teachers Training at UIN Mataram reflected good improvement. The overall scores from the questionnaires which were administered to students inclined 0.014 from 2018 to 2019. There was also a department that jumped in score from 3.03 in 2018 to 3.44 in 2019 which reflected the importance of AQA for any level in higher education system. Also, the department at UIN Mataram faced institution accreditation under the national board of accreditation that might be the external factor causing the quality improvement. The phenomena depicted by TBI (English Education Department) lecturers' performance score improved 0.24 in 2019. Moreover, lecturers' habit in teaching has shown better performance by being more punctual in 2019 than in 2018.

The result of survey also emphasized on some points that should be put as suggestion for better academic quality in the university. Furthermore, the future research is expected to discuss the AQA in wider context with more causal variables.

\section{Acknowledgment}

This research was supported by the Quality Assurance Bureau at State Islamic University, Mataram, NTB, Indonesia as the data provider for the present research.

\section{References}

Anggraeni, R. D. (2014). Increasing Lecturer Competence as the Quality Assurance of Lecturer Performance. Management Studies, 2(5), 309-329.

Bancin, A. (2017). Sistem Penjaminan Mutu Perguruan Tinggi. Jurnal Manajemen Pendidikan, 9(1). Retrieved from https://jurnal.unimed.ac.id/2012/index.php/jmpi/article/view/9723

Barnett, R. (1992). Improving higher education: Total quality care. Bristol, PA: SRHE and Open University Press.

Green, M. F., Marmolejo, F., \& Egron-Polak, E. (2012). The internationalization of higher education: Future prospects. In D. K. Deardorff, H. de Wit, J. D. Heyl, \& T. Adams (Eds.), The SAGE handbook of international higher education (pp. 439-457). Thousand Oaks, CA: SAGE. https://doi.org/10.4135/9781452218397.n24

Harvey, L. (2014). Quality. In Analytic quality glossary. Retrieved from http://www.qualityresearchinternational.com/glossary/quality.htm

Hinton, P. R., McMurray, I., \&. Brownlow, C. (2014). SPSS explained. 2nd ed. New York: Routledge. 
https://doi.org/10.4324/9781315797298

Liu, Shuiyun, Tan, Minda, \& Meng, Zhaorui. (2015). Impact of Quality Assurance on Higher Education Institutions: A Literature Review. Higher Education Evaluation and Development, 9, 17-34. http://doi.org/10.6197/HEED.2015.0902.02

Lundberg, C. A., \& Schreiner, L. A. (2004). Quality and frequency of faculty-student interaction as predictors of learning: An analysis by student race/ethnicity. Journal of College Student Development, 45(5), 549-565. http://doi.org/10.1353/csd.2004.0061

Martin, P. A. (2019). Student Perceptions of a Good University Lecturer. Educ. Pesqui, 45(18). Retrieved from http://orcid.org/0000-0003-1536-6163

Neihart, Maureen, \& Ling, Lee. (2017). Quality Assurance in Teacher Education in Singapore. https://doi.org/10.1007/978-981-10-3386-5_16

Pakpahan, Valen O., Haryono, \& Joseph, A. (2017). Enhancement of Quality and Professionalism Lecturer in Semarang Akpelni Judging from the HR process. Educational Management, 6(1), 20-25. Retrieved from http://journal.unnes.ac.id/sju/index.php/eduman

Puzziferro, M., \& Shelton, K. (2008). A model for developing high-quality online courses: Integrating a systems approach with learning theory. Journal of Asynchronous Learning Networks, 12(3-4). Newbury, MA: Online Learning Consortium. https://doi.org/10.24059/olj.v12i3.58

Rusdarti, \& Sucihatiningsih, D. W. P. (2017). Against Accountability Accreditation Quality Assurance Graduate Studies Program at the State University of Semarang. Educational Management, 6(2), 196-207. Retrieved from http://journal.unnes.ac.id/sju/index.php/Eduman

Saeed, Sameerah, \& Saeed, Samira. (2018). Impact of Quality Assurance on Academic Performance. International Journal of Social Sciences \& Educational Studies, 5. http://dx.doi.org/10.23918/ijsses.v5i1p178

Schindler, L., Puls-Elvidge, S., Welzant, H., \& Crawford, L. (2015). Definitions of quality in higher education: A synthesis of the literature. Higher Learning Research Communications, 5(3), 3-13. http://doi.org/10.18870/hlrc.v5i3.244

Setiyaningrum, I. (2012). Impact of Implementation of ISO 9001: 2000 And Organizational Culture On Employee Performance In LPMP Central Java Perceptual Study On LPMP Employees. Educational Management, 1(1). Retrieved from http://journal.unnes.ac.id/sju/index.php/eduman

Siram, R. (2015). Manajemen Penjaminan Mutu Layanan Akademik Perguruan Tinggi. Jurnal Ilmu Pendidikan, 21(1). http://doi.org/10.17977/jip.v21i1.6483

Smidt, H. (2015). European quality assurance-A European higher education area success story [overview paper]. In A. Curaj, L. Matei, R. Pricopie, J. Salmi, \& P. Scott (Eds.), The European higher education area: Between critical reflections and future policies (pp. 625-637). London, UK: Springer Open. http://doi.org/10.1007/978-3-319-20877-0_40

Suarman, Suarman, Aziz, Zahara, \& Mohammad Yasin, Ruhizan. (2013). The Quality of Teaching and Learning towards the Satisfaction among the University Students. Asian Social Science, 9, 252-260. http://doi.org/10.5539/ass.v9n12p252

Suhendro. (2003). Manajemen, Edisi ke 2. Bandung. Al-fabeta.

Suratno, \& Zulaeha, I. (2019). Academic Quality Assurance System Madrasah Targets Madrasah. EM, 8(2), 248-253

Vlăsceanu, Lazăr, Grunberg, Laura, \& Pârlea, Dan. (2005). Quality Assurance and Accreditation: A Glossary of Basic Terms and Definitions. Retrieved http://lst-iiep.iiep-unesco.org/cgi-bin/wwwi32.exe/[in=epidoc1.in]/?t2000=024133/(100)

Westerheijden, D. F., Stensaker, B., \& Rosa, M. J. (eds). (2007). Quality Assurance in Higher Education:Trends in Regulation, Translation and Transformation. Dordrecht: Springer. https://doi.org/10.1007/978-1-4020-6012-0

\section{Copyrights}

Copyright for this article is retained by the author(s), with first publication rights granted to the journal.

This is an open-access article distributed under the terms and conditions of the Creative Commons Attribution license (http://creativecommons.org/licenses/by/4.0/). 